\title{
EVALUATION OF KI-67, APOPTOSIS, AND HYALURONIC ACID IN GRADING RETINOBLASTOMA
}

\author{
Hendrian D Soebagjo ${ }^{1}$, Nurwasis ${ }^{1}$, Ugroseno Y Bintoro ${ }^{2}$, Sutiman B Soemitro ${ }^{3}$ \\ ${ }^{1}$ Department of Ophthalmology, ${ }^{2}$ Department of Hematology, Faculty of Medicine, Universitas Airlangga, Dr. Soetomo \\ Hospital, Surabaya, ${ }^{3}$ Department of Biology, Faculty of Science, Universitas Brawijaya, Malang, Indonesia
}

\section{ABSTRACT}

Hyaluronic acid (HA) is a glycosaminoglycan with a straight-chain polymer arrangement defined as the extracellular matrix constituent. High molecular weight HA has normal physicochemical, biological, and physiological properties whereas low molecular weight has the property of angiogenesis, inflammation, and suppresses apoptosis. This study occupied the samples of 35 paraffin block from poorly and well differentiated retinoblastoma tissue and 8 normal retinal block which have been collected for 4 years from 2010-2013 at Dr. Soetomo Hospital, Surabaya, Indonesia. Afterwards, the paraffin blocks were immunohistochemically examined for HA staining, expression of cell proliferation (Ki-67), and cell apoptosis to determine intratumoral aggressiveness of retinoblastoma. HA on poorly differentiated retinoblastoma stain with a high immunostaining of $76.2 \%$, while well differentiated retinoblastoma on the highest HA staining was revealed to be at moderate level of $64.3 \%$, and not appear in normal retina. In poorly differentiated retinoblastoma, the location of most HA stain is in the cell cytoplasm (87.5\%). In the well differentiated retinoblastoma, the HA immunostaning mainly occurred in the cell membrane (73.7\%). Histopathological retinoblastoma grading showed a significant correlation ( $p<0.01)$ towards several variables of HA immunostaining, Ki-67, and cell apoptosis. In addition, the histopathological retinoblastoma grading also revealed a significant correlation $(p<0.01)$ towards the location of HA staining (cell membrane and cytoplasm). Both stainings are also play role in retinoblastoma differentiation. The malignancy of retinoblastoma can be proven by the increased HA staining at cytoplasm in poorly differentiated and associated with increased of cell proliferation along with decreased apoptosis.

Keywords: Hyaluronic acid; retinoblastoma; aggressiveness

\section{ABSTRAK}

Asam hialuronat (HA) merupakan senyawa glikosaminoglikan dengan polimer rantai lurus yang berfungsi mengisi matriks ekstraseluler. HA dengan berat molekul besar memiliki sifat fisikokimia, biologis, dan fisiologis normal sedangkan berat molekul rendah berperan dalam proses angiogenesis, inflamasi, dan supresi apoptosis. Penelitian ini menggunakan 35 sampel blok parafin jaringan poorly dan well differentiated retinoblastoma serta 8 blok retina normal yang dikoleksi selama 4 tahun dari tahun 20102013 di RSUD Dr. Soetomo, Surabaya, Indonesia. Setelah itu, blok parafin diuji imunohistokimia dengan pewarnaan HA, ekspresi proliferasi sel (Ki-67), dan apoptosis sel untuk melihat agresivitas retinoblastoma intratumoral. Pewarnaan HA pada poorly differentiated retinoblastoma menunjukkan pewarnaan yang tinggi sebesar $76.2 \%$, sedangkan pada well differentiated retinoblastoma menunjukkan pewarnaan yang tinggi pada tingkat sedang sebesar $64.3 \%$, dan tidak muncul pada retina normal. Pada poorly differentiated retinoblastoma, rata-rata pewarnaan HA muncul di sel sitoplasma (87.5\%). Pada well differentiated retinoblastoma, pewarnaan HA rata-rata muncul di area membran sel (73.7\%). Grading histopatologis retinoblastoma menunjukkan korelasi signifikan terhadap beberapa variabel yaitu pewarnaan HA, Ki-67, dan apoptosis sel (p <0.01). Selain itu secara histopatologis juga menunjukkan korelasi yang signifikan ( $p<0.01)$ terhadap lokasi pewarnaan HA (membran dan sitoplasma sel). Keduanya juga berperan penting terhadap diferensasi retinoblastoma. Keganasan retinoblastoma dapat ditunjukkan dengan adaya peningkatan pewarnaan HA di sitoplasma pada poorly differentiated retinoblastoma dan berhubungan dengan peningkatan proliferasi serta penurunan apoptosis sel.

Kata kunci: Asam hialuronat; retinoblastoma; agresivitas

Correspondence: Hendrian D. Soebagjo, Department of Ophthalmology, Faculty of Medicine, Universitas Airlangga, Dr. Soetomo Hospital, Surabaya, Indonesia. E-mail: hendriands@yahoo.com

pISSN:2355-8393 • eISSN: 2599-056x • doi: http://dx.doi.org/10.20473/fmi.v55i3.15504

- Fol Med Indones. 2019;55:206-212 • Received 21 May 2019 • Accepted 8 Aug 2019

- Open access under CC-BY-NC-SA license • Available at https://e-journal.unair.ac.id/FMI/ 


\section{INTRODUCTION}

Retinoblastoma is the most malignant of primary intraocular tumor in children. It is deemed as aggressive as it often causes blindness, morbidity and mortality. The life expectancy of retinoblastoma patients is still rather low. Retinoblastoma grading systems including the primary tumor size and the presence of metastasis in lymph nodes as well as distant metastasis are still not able to be implemented as definitive indicators of prognosis. This is because the accuracy of conventional indicators is not as exact as desired. On top of that, the mechanism of growth, cell death, and aggressiveness is not fully understood, causing further inefficiency in the implementation of systemic therapy. Therapy for retinoblastoma using biomolecular applications has also not shown any good results. HA with CD44 (Cluster Differentiation 44) as a receptor, MMP-14 (Matrix of Metaloproteinase-14), EZH2 (Enhancer of Zeste Homolog 2), proliferation, and apoptosis have been proven to play an essential role in the process of cancer aggressiveness. However, in retinoblastoma, it remains to be a matter of debate since the role has not been clear until today (McKee and McKee 2008, Sitorus et al 2009, Berge et al 2010).

HA is a glycosaminoglycan with a composition of the straight chain polymer arrangement which is an extracellular matrix constituent and is composed of disaccharide components (D-glucuronic acid and D-Nacetyl glucosamine). HA is divided into two categories: firstly, high molecular weight HA which has normal physicochemical, biological, and physiological properties with a molecular weight of about 2 x $106 \mathrm{Da}$ to $2 \times 107 \mathrm{Da}$ or $2500-25,000$ disaccharides in cell membranes (Lee and Spicer 2000, Noble et al 2002, Toole 2002, Stern et al 2006, Evanko et al 2007). Such type of HA is found in cell membranes due to its large molecular weight and it cannot enter the cytoplasm. HA is recognized to be appeared in various types of cancer including tonsillar cancer (Clark et al 1996), prostate cancer (Toole 2002, Bharadwaj et al 2009), glioma (Wiranowska \& Rojiani 2011), and breast cancer (Louderbrough \& Schroeder 2011).

Secondly, low molecular weight HA with polymer length of 2-25 $\mu \mathrm{m}$ in oligosaccharide fragments form (Stern et al 2006, Evanko et al 2007) has the properties of angiogenesis (Toole 2002), suppresses cell apoptosis, induces CD44 division, FasL regulation (Stern et al 2006), adhesion, and migration by activating several signalling pathways such as adhesion kinase, mitogenactivated protein (MAP) kinase pathway (Rossler \& Hinghofer-Szalkay 2003, Murai et al 2004) and tyrosine kinase cascade (Lokeshwar \& Selzer 2000), also stimulates the production of inflammatory cytokines
(Noble et al 2002, McKee et al 2008), and inhibits anchorage-independent to affect the growth of several types of tumor cells (Ghatak et al 2012, Misra et al 2012).

\section{MATERIALS AND METHODS}

This research was conducted as observational analysis with cross-sectional design. Paraffin block specimens were processed from normal retinoblastoma and retinal tumor tissue of enucleated eye who have never encountered chemotherapy. The samples were 35 retinoblastoma block samples (poorly and well differentiated retinoblastoma) and 8 normal retinal block samples which have been collected for 4 years, from 2010 - 2013 at Dr.Soetomo General Hospital, Surabaya, Indonesia.

Paraffin blocks cut and HE staining was carried out. Afterwards, it was continued with re-examination to confirm the differentiation of retinoblastoma and normal retina. Paraffin blocks were then immunohistochemically assessed to determine intratumoral aggressiveness of retinoblastoma by examining the immunostaining of $\mathrm{HA}$, cell proliferation expression with $\mathrm{Ki}-67$, and cell apoptosis with TUNEL. All samples tested for both differentiation on histopathological and immunohistochemical grading were re-examined by two pathologists in which it was conducted in unrelated different places. HA staining using primary antibodies towards Anti-HA antibodies (ab53842) Abcam Inc. (1: 300), Ki-67 expression using (CRM325 AK, BK) - Biocare Medical monoclonal antibodies (1:75), and apoptotic cell using TACS ${ }^{\circ}$ 2TdT DAB IN Situ Apoptosis (4810-30-K) Trevigen, Inc. (1: 1000). All samples were coloured using the Labelled Streptavidin Biotin II (LSAB II) method.

Positive control tissues included tonsillar cancer (HA) and prostate cancer (Ki-67). The intensity of HA staining was assessed with the proportion of the percentage of positive colouring categories: low $(<35 \%)$, moderate $(35-75 \%)$, and high $(=75 \%)$. Ki-67 expression in nucleus cells was negative $(0 \%)$, low $(=40 \%)$, and high $(=40 \%)$. Positive apoptotic cell staining is defined as the total cell expressing the nucleus. Apoptotic cell numbers were calculated using a standard light microscope with Axio Vision, Carl Zeiss Microscopy (Voutilainen et al 2003, Wang et al 2016, Urbanska et al. 2015).

The collected data were analyzed using Chi SquareKruskall Wallis Test to assess the differences among the retinoblastoma grading. The Spearmann correlation test was used to analyze the correlation of immunostaining, 
expression variables, and their location. A value of $\mathrm{p}$ $<0.05$ was considered statistically significant.

\section{RESULTS}

\section{Histopathologic grading in retinoblastoma}

Examination was conducted to distinguish sample preparations which are classified as poorly differentiated retinoblastoma, well differentiated retinoblastoma, and normal retina as a comparison (Fig. $1)$.

\section{Expression of HA and its location}

According to the histopathological grading, HA in poorly differentiated retinoblastoma showed HA with a high immunostaining of $76.2 \%$ while the rest shows low and medium immunostaining. In well differentiated retinoblastoma, the highest $\mathrm{HA}$ immunostaining is moderate immunostaining of $64.3 \%$ and the rests are low $(28.6 \%)$ and high $(7.1 \%)$ immunostaining. In the entire normal retina samples, there were no HA. Chi Square analysis between grading in the normal retina compared to poorly differentiated retinoblastoma and well differentiated retinoblastoma showed significant results $(\mathrm{p}<0.05)$. In view of the results of the analysis, it was concluded that HA immunostaining was higher in the poorly differentiated retinoblastoma.

Histopathologically, HA is appeared in the cytoplasm and cell membrane. HA immunostaining in the cell membrane is in rosette surrounding. It is also observed in poorly differentiated retinoblastoma cell membranes but not as clear as in well differentiated; nonetheless, its immunostaining is very high in the cell cytoplasm. HA on the normal retina is not shown. In poorly differentiated retinoblastoma, the location of most HA immunostaining is in the cell cytoplasm $(87.5 \%)$ whereas in the well differentiated retinoblastoma, the highest immunostaining of HA is in the cell membrane (73.7\%) (Fig.2). On the contrary, HA was not observed in the normal retina. In accordance with the Chi-Square analysis, the immunostaining of $\mathrm{HA}$ in the membrane location and cytoplasm of retinoblastoma cells towards its gradation resulted in a significant difference ( $p$ $<0.05$ ) (Table 1). This shows that the location of HA immunostaining has a role on retinoblastoma grading.

\section{Cell proliferation}

Ki-67 was highly expressed in all poorly differentiated retinoblastoma samples $(100 \%)$ whereas in well differentiated retinoblastoma, most of the expressions were low $(78.6 \%)$ and the rests were not seen to be expressed. Normal retinal cells do not express Ki-67. $\mathrm{Ki}-67$ expression on the normal retina towards poorly differentiated retinoblastoma and well differentiated retinoblastoma showed significant results $(p<0.05)$, as well as between poorly differentiated and well differentiated retinoblastoma $(\mathrm{p}=0.000)$. The analysis shows that $\mathrm{Ki}-67$ expression increases with the deterioration in the differentiation of retinoblastoma.

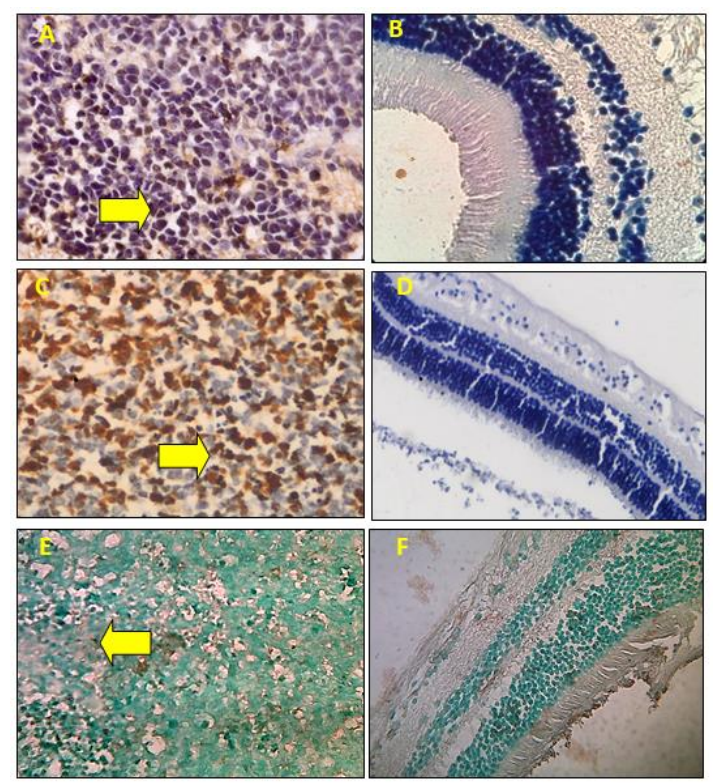

Fig. 1. Immunohistochemical staining pattern of HA, $\mathrm{Ki}-67$, and apoptotic cells in retinoblastoma and normal retina samples. A. HA appear at cytoplasm in retinoblastoma sample. Objective 40x. B. HA did not appear in normal retina. Objective 20x. C. Retinoblastoma cells overexpressing Ki-67 with nuclear staining. Objective 40x. D. Ki-67 was not expressed in normal retina. Objective 20x. E. Retinoblastoma cells expressing apoptotic cells with a brown colour nuclear staining. Objective 20x. F. Apoptotic cell is not expressed in normal retina. Objective $20 x$.

\section{Apoptosis}

Apoptotic cells are found in almost all cases of retinoblastoma but none are found in the normal retina. The average number of apoptotic cells is 5.35 cells per visual field. Apoptosis expression in each histopathological grading of retinoblastoma has different characteristics. Apoptosis in poorly differentiated retinoblastoma was expressed lower than well differentiated retinoblastoma. The number of cells experiencing expressed apoptosis is approximately at average of 1.06 cells in poorly differentiated retinoblastoma whereas in well differentiated retinoblastoma, it is proven to be expressed as much as 4.34 cells. Despite that, cell apoptosis does not occur in the normal retina. 
Table 1. Immunohistochemical staining results on HA

\begin{tabular}{|c|c|c|c|c|c|}
\hline \multirow[t]{2}{*}{ Grading } & \multicolumn{3}{|c|}{ HA Immunostaining } & \multicolumn{2}{|c|}{ Location } \\
\hline & Low & Moderate & High & Membrane & Cytoplasm \\
\hline Poorly & $3(14.3 \%)$ & $2(9.5 \%)$ & $16(76.2 \%)$ & $3 \quad(12.5 \%)$ & $21(87.5 \%)$ \\
\hline Well & $4(28.6 \%)$ & $9(64.3 \%)$ & $1(7.1 \%)$ & $14(73.7 \%)$ & $5(26.3 \%)$ \\
\hline Normal & $0(0 \%)$ & $0(0 \%)$ & $0 \quad(0 \%)$ & $0 \quad(0 \%)$ & $0 \quad(0 \%)$ \\
\hline
\end{tabular}

Table 2. Association between variables towards retinoblastoma grading

\begin{tabular}{lccc}
\hline & \multirow{2}{*}{ Variables } & & \multicolumn{2}{c}{ Retinoblastoma Grading } \\
\cline { 3 - 4 } & & P value & Significance \\
\hline Immunostaining & HA & 0.757 & $0.000 * *$ \\
\hline Expression & Ki-67 & 0.924 & $0.000^{* *}$ \\
& Apoptosis & 0.492 & $0.000^{* *}$ \\
\hline HA Staining Location & Membrane & -0.956 & $0.000^{* *}$ \\
& Sitoplasma & 0.878 & $0.000^{* *}$ \\
\hline *** Significant $(\alpha<0.01)$ & & &
\end{tabular}

**Significant $(\alpha<0.01)$

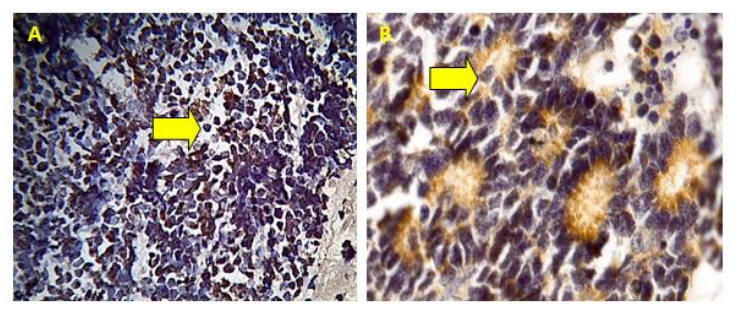

Fig. 2. Immunohistochemical staining pattern of HA in retinoblastoma samples. A. HA appeared at cytoplasm in retinoblastoma sample. Objective 40x. B. HA appeared at cell membrane well differentiated retinoblastoma. Objective 100x.

Chi Square statistical test - Kruskal Wallis on apoptotic cell showed significant results (a: $0.000, \mathrm{p}<0.05$ ) in all histopathological gradations. The number of cells that showed apoptosis indicated significant results $(\mathrm{p}<0.05)$. Statistical tests of apoptotic expression in each gradation showed significant results on the normal retina against poorly differentiated retinoblastoma and well differentiated retinoblastoma $(\mathrm{p}<0.05)$. Significant results were also obtained between poorly differentiated retinoblastoma towards well differentiated retinoblastoma $(\mathrm{p}<0.05)$. This indicates that the worse the differentiation of retinoblastoma based on histopathological grading is, the lower apoptosis is.

\section{Inter-variable test}

Correlation test between expressions shows that histopathological grade of retinoblastoma has led to a significant correlation ( $\mathrm{p}<0.01)$ for HA immunostaining variables (p: 0.757; a; 0.000), Ki-67 (p: 0.924; a; 0.000), and apoptotic cells (p: 0.492; a; 0.000). In addition, the histopathological retinoblastoma grading also showed a significant correlation $(\mathrm{p}<0.01)$ towards the location of HA immunostaining, i.e. in the cell membrane (p: 0.956; a; 0.000) and cell cytoplasm (p: 0.878; a; 0.000).

This shows that HA immunostaining, proliferation, and apoptotic cell retinoblastoma have a strong influence on the retinoblastoma grading. The location of the immunostaining of HA itself also has a strong effect in this case. The immunostaining of $\mathrm{HA}$ in the cell cytoplasm will affect the grading of retinoblastoma to be more malignant/more poorly differentiated and the immunostaining of hyaluronic acid in the cell membrane will affect the grading in well differentiated retinoblastoma. These results indicate that the location of HA immunostaining is a strong discriminant factor in distinguishing histopathological grading of retinoblastoma as an aggressive parameter of retinoblastoma.

\section{DISCUSSION}

Based on the results of the correlation test, HA immunostaining, cell proliferation, and cell apoptosis have an association with histopathological grading of retinoblastoma. The test reveals that HA has a role in retinoblastoma cell malignancy and plays a role in the process of differentiation of retinoblastoma cells. This is consistent with the study conducted by Posey et al (2003) and Tahmatzopoulos et al (2012) which showed an increasing role of HA in prostate cancer when compared to benign prostate hyperplasia and normal cells. In prostate cancer, the immunostaining of HA is not localized only to the prostate gland, but it has spread to the high-grade stromal region. Rangel et al (2015) also reported on lung cancer showing that a significant 
immunostaining of HA is encountered when compared to normal tissue and sputum samples. Li et al (2016) also further asserted that HA over immunostaining would have a biological effect on the progression of hepatic carcinoma. While Gao et al (2016) discerned the role of HABP-1 as HA protein binding whose immunostaining increases as an HA elevation indicator which increases the progression of gastric cancer cells and decreases the patients survival rate.

HA immunostaining is able to induce cell proliferation process; yet, it does not affect cell apoptosis. This means that HA has a role in the aggressiveness of retinoblastoma cells. The imbalance between cell apoptosis and proliferation, which is characterized by an increase in the expression of proliferation indicators, $\mathrm{Ki}$ 67 can be discerned as tumorigenesis and aggressiveness of the tumor. Ki-67 expression and apoptosis are strong discriminant function to differentiate histopathological grading of retinoblastoma as a parameter of aggressiveness in retinoblastoma. The aggressiveness of cancer cells can be determined based on cell proliferation, cell nucleus, angiogenesis, necrosis, and tumor cell apoptosis. The imbalance between cell apoptosis and proliferation indicates tumorigenesis and aggressiveness of the tumor. Proliferation and apoptosis imbalances to measure the level of aggressiveness of cancer are detected in breast cancer, lung cancer, gastric cancer, and retinoblastoma cancer (Liu et al 2001, Trihia et al 2003, Sitorus et al 2009, Soebagjo et al 2013).

HA immunostaining induces proliferation signals through its main receptor, CD44, then the interaction of HA with CD44 can increase invasion, motility and proliferation of tumor cells. The HA-CD44 complex triggers the receptor tyrosine kinase signalling process, other signal receptors (TGFßR1), and non-receptor kinase, and through the MAP kinase pathway and induces proliferation via the CDK-2 pathway by suppressing the inhibitor, p27 (kip1) and hyperphosphorylation of $\mathrm{Rb}$ protein and CD44 differently expresses the BMI1 gene (Gadhoum et al 2004, Loderbough \& Schroeder 2011, Naor 2016, Patel et al 2017).

Based on its location on its histopathological grading, HA is appears in the cytoplasm and cell membrane. HA immunostaining in the cell membrane is in rosette surrounding. It is also appears in poorly differentiated retinoblastoma cell membranes but not as clearly as in well differentiated. Even so, its immunostaining is very high in the cell cytoplasm. In the normal retina, HA does not appear. HA which appears in cell membranes has a high molecular weight, about 4 x $106 \mathrm{Da}$ or 25,000 disaccharides. This high molecular weight HA is produced by the HAS 1 gene at residu chromosome 19 q13.3-13.4 and HAS2 on chromosome 8 q24.12. This type of HA is found in cell membranes because of its large molecular weight and cannot enter the cytoplasm. This high molecular weight HA still has good properties, which can inhibit tumor development, antiangiogenic, inhibit endothelial cell growth, and maintain the balance among cells (Stern et al 2006, Marques 2011, Siiskonen 2013).

Structurally, the retina is formed from two layers, namely the retinal pigment epithelium (RPE) on the external side and the retinal nerve on the inner side. This structure is maintained because of the role of HA in maintaining balance among cells. In the histopathological well differentiated retinoblastoma with rosette characteristics, it shows that the range of retinoblastoma cells is centred on the axis. The rosette shaft proves that there is still a role for HA through immunohistochemical staining. Physiologically, HA attracts retinoblastoma cells to align and form rosette through three types of clusters that have modification capabilities, namely hydroxyl, carboxyl, and acetamid groups. Scott et al (1989) revealed that hydrogen bonds as the axis of the N2 acetamid and G1 carboxyl groups in HA. In consequence, G1 and N1 disaccharides can rotate 180 degrees on the axis to move with disaccharide G2 and N2. This causes carboxyl groups, acetamides, and hydroxyl HA, which has diamagnetic properties, can bind large amounts of water up to 6 liters in each gram of HA with a double helix structure and form a matrix to stabilize the intercellular structure (Scott et al 1989, Leach \& Schmidt 2004).

In the well differentiated retinoblastoma grading, the reduced immunostaining of $\mathrm{HA}$ in the cell membrane in retinoblastoma causes some empty space between cells so that HA loses some function of filling space between molecules in the network matrix, of attracting and binding water into the solvent domain, and of stabilization inter cell structure. Reduced HA immunostaining in cell membranes can be caused by various factors. Functionally, it can occur due to a decrease in the synthesis of HAS1 or HAS2 genes that produce high molecular weight HA or increased HYAL gene synthesis which degrades hyaluronic acid into abnormal fragments with the assistance of hyaluronidase enzymes and enters the cell cytoplasm. Moreover, it can occur due to increased HAS3 gene synthesis producing low molecular weight HA. The decrease in HA production in the retinoblastoma cell membrane lead to retinoblastoma cells to lose orientation between cells so that their characteristics change to poorly differentiated retinoblastoma cells that are malignant (Scott et al 1989, Bharawadj 2009, Siiskonen 2013). 
Stern et al (2006) mentioned that HA contained in the cell cytoplasm has a low molecular weight, with a polymer length of 2-25 $\mu \mathrm{m}$, and in the form of oligosaccharide fragments. This type of HA has the properties of angiogenesis, suppresses cell apoptosis, induces CD44 division, adhesion, and migrates by activating several signalling pathways such as adhesion kinases, pathways MAP kinase, and kinase cascades. This type of HA is produced by the HAS3 gene on chromosome 16q22.1. Therefore, a low molecular weight HA appears in the cytoplasm has more properties capable of inducing malignancy in retinoblastoma cells. The results of this study indicate that HA immunostaining affects retinoblastoma cell proliferation. However, HA does not affect cell apoptosis expression. This is consistent with the immunostaining of $\mathrm{HA}$ in prostate cancer, ovarian cancer, and breast cancer (Lee \& Spicer 2000, Stern et al 2006, Tahmatzopoulos et al 2012, Siiskonen 2013).

\section{CONCLUSION}

HA immunostaining in cytoplasm and the cell membrane. Both expression had a active role in the retinoblastoma differentiation. That differentiation affected to make a retinoblastoma aggresive, it has been proved by the increased HA immunostaining at cytoplasm in poorly differentiated and associated with increased of cell expression proliferation along with decreased apoptosis.

\section{REFERENCES}

Berge EO, Knappskog S, Geisler S, Staalesen V, Pacal M., Puntervol P, et al (2010). Identification and characterization of retinoblastoma gene mutations disturbing apoptosis in human breast cancers. Mole. Cancer 9,173

Bharadwaj AG, Kovar JL, Loughman E, Elowsky C, Oakley GG, Simpson MA (2009). Spontaneous metastasis of prostate cancer is promoted by excess hyaluronan synthesis and processing. Am J Pathol. 174,1027-36

Blundell CD, Deangelis PL, Almond A (2006). Hyaluronan: the absence of amide-carboxylate hydrogen bonds and the chain conformation in aqueous solution are incompatible with stable secondary and tertiary structure models. Biochem J 396, 487-98

Clark RA, Alon R, Springer TA (1996). CD44 and hyaluronan-dependent rolling interactions of lymphocytes on tonsillar stroma. J Cell Biol. 134, 1075-87
Evanko SP, Tammi MI, Tammi RH, Wight TN (2007). Hyaluronan-dependent pericellular matrix. Advanced Drug Delivery Reviews 59, 1352-1365

Gadhoum Z, Delaunay J, Maquarre E, Durand L, Lancereaux V, Qi J, et al (2004). The Effect of antiCD44 monoclonal antibodies on differentiation and proliferation of human acute myeloid leukemia cells. Leukemia \& Lymphoma 45, 1501-1510

Gao H, Yao Q, Lan X, Li S, Wu J, Zeng G, Xue Y (2016). Elevated HABP1 protein expression correlates with progression and poor survival in patients with gastric cancer. OncoTargets and Therapy 9, 67116718

Ghatak S, Hascall VC, Karamanos NK, Markwald RR, Misra S (2012). Targeting the tumor microenvironment in cancer progression. In Karamanos N, editor. Extracellular Matrix: Pathobiology and Signaling. Berlin, DeGruyter, p 729-46

Jaime MC, Carol ST, and Garantziotis S (2015). Size matters: Molecular weight specificity of hyaluronan effects in cell biology. International Journal of Cell Biology

Leach JB, Schmidt CE (2004). Hyaluronan. In: Bowlin GL, Wnek G. Encyclopedia of biomaterials and biomedical engineering. Informa Healthcare

Lee JY, and Spicer AP (2000). Hyaluronan: a multifunctional, megadalton, stealth molecule. Current Opinion in Cell Biology 12, 581-586

Li JH, Wang YC, Qin CD, et al (2016). Over expression of hyaluronan promotes progression of $\mathrm{HCC}$ via CD44-mediated pyruvate kinase M2 nuclear translocation. Am J Cancer Res 6, 509-21

Liu S, Edgerton SM, Moore DH, Thor AD (2001). Measures of cell turnover (proliferation and apoptosis) and their association with survival in breast cancer. Clin Cancer Res 7, 1716-1723

Lokeshwar VB and Selzer MG (2000). Differences in hyaluronic acid-mediated functions and signaling in arterial, microvessel, and vein-derived human endothelial cells. J Biol Chem 275, 27641-27649

Louderbough JMV and Schroeder JA (2011). Understanding the Dual Nature of CD44 in Breast cancer Progression. Mol Cancer Res 9,12

Marques ACF (2011). Investigation of The Effect of Structured Hyaluronic Acid Surfaces On Cell Proliferation and Expression of HA Cellular Receptors: CD44 and RHAMM. A thesis. Cranfield University.

McKee T and McKee JR (2008). Biochemistry in Perspective: Carcinogenesis. In: Biochemistry: The Molecular Basis of Life. 4th Ed. USA, Oxford University Press

Misra S, Hascall VC, Markwald RR, Ghatak S. 2015. Interactions between Hyaluronan and Its Receptors (CD44, RHAMM) Regulate the Activities of Inflammation and Cancer. Front Immunol 6, 201 
Murai T, Miyazaki Y, Nishinakamura H, Sugahara KN, Miyauchi T, Sako Y, et al (2004). Engagement of CD44 promotes Rac activation and CD44 cleavage during tumor cell migration. J Biol Chem 279, 45414550

Naor D (2016). Editorial: Interaction Between Hyaluronic Acid and Its Receptors (CD44, RHAMM) Regulates the Activity of Inflammation and Cancer. Front Immunol 7, 39

Noble PW (2002). Hyaluronan and its catabolic products in tissue injury and repair. Matrix Biology 21, 25-29

Patel S, Shaikh F, Devaraji V, Radadiya A, Shah K, Shah A, Rawal R (2017). Insights into the structural perturbations of spliced variants of CD44: a modeling and simulation approach. Journal of Biomolecular Structure and Dynamics 35, 354-367

Posey JT, Soloway MS, Ekici S, Sofer M, Civantos F, Duncan RC, and Lokeshwar VB (2003). Evaluation of the Prognostic Potential of Hyaluronic Acid and Hyaluronidase (HYAL1) for prostate cancer. Cancer Research 63, 2638-2644

Rangel MP, de Sá VK, Martins V, et al (2015). Tissue hyaluronan expression, as reflected in the sputum of lung cancer patients, is an indicator of malignancy. Braz J Med Biol Res. 48, 557-67

Rössler A, Hinghofer-Szalkay H (2003). Hyaluronan fragments: an information-carrying system? hypothesis. Hormone and Metabolic Research 35, 678

Scott JE (1989). Secondary structures in hyaluronan solutions: chemical and biological implications. The Biology of Hyaluronan. Ciba Foundation Symposium 143, 6-14

Siiskonen H (2013). Hyaluronan and hyaluronan synthases. A dissertation in Health Sciences. Kuopio, University of Eastern Finland

Sitorus RS, Saukani G, Valk PVD (2009). The apoptosis paradox in retinoblastoma. Natural compounds and their role in apoptotic cell signaling pathways. Ann NY Acad Sci 1171, 77-86

Soebagjo HD, Prastyani R, Sujuti H, Lyrawati D, Sumitro SB (2013). Profile of Retinoblastoma in East Java, Indonesia. World Journal of Medicine and Medical Science Research 1, 051-056

Stern, R., A.A. Asari, and K.N. Sugahara. 2006. Hyaluronan fragments: An information-rich system. European J. Cell. Biol. 85, 699-715

Tahmatzopoulos A, Papakonstantinou E, Kotakidou R, Hatzihristou D, Karakiulakis G (2012). Immunohistochemical expression of hyaluronic acid in the normal prostate, benign prostate hyperplasia and prostate carcinoma. Aristotle University Medical Journal 39, 1-6

Toole BP (2002). Hyaluronan promotes the malignant phenotype. J Gly 12, 37R-42R

Trihia H, Murray S, Price K, Gelber RD, Golouh R, Goldhirsch A, et al (2003). Ki-67 expression in breast carcinoma: its association with grading systems, clinical parameters, and other prognostic factors--a surrogate marker? Cancer. 97, 1321-31

Urbanska K, Sokolowska J, Szmidt M, Sysa P (2014). Proliferative and Apoptotic Activity of Glioblastoma Multiforme Cells Cultured on In Ovo Model. In Vivo $28,541-548$

Voutilainen K, Anttila M, Sillanpää S, Tammi R, Tammi M, Saarikoski S, Kosma V (2003). Versican in epithelial ovarian cancer: relation to hyaluronan, clinicopathologic factors and prognosis 22, 103-15

Wang W, Wu J, Zhang P, Fei X, Zong Y, Chen X, et al (2016). Prognostic and predictive value of Ki-67 in triple-negative breast cancer. Oncotarget 7, 3107931087

Wiranowska, M and Rojiani MV (2011). Extracellular Matrix Microenvironment in Glioma Progression, 12. Glioma - Exploring Its Biology and Practical Relevance, Dr. Anirban Ghosh (Ed.) InTech, p 257-284 